\title{
New extension range of Nyctinomops macrotis Gray, 1840 (Chiroptera: Molossidae) in Southern Andes of Ecuador
}

\section{Francisco Sánchez-Karste1, Carlos Nivelo-Villavicencio ${ }^{2 * *}$, Javier Fernández de Córdova ${ }^{2}$ and Pedro X. Astudillo²}

${ }^{1}$ Programa de biodiversidad. Parque Nacional Cajas. Subgerencia de Gestión Ambiental - ETAPA EP. 010150 Cuenca. Ecuador.

2Laboratorio de Ecología. Escuela de Biología. Ecología y Gestión. Universidad del Azuay. Av. 24 de mayo 7-77 y Hernán Malo. Apartado 01.01.981. Cuenca. Ecuador. *Email: cvillavicencio@uazuay.edu.ec.

Abstract. This study reports a new range-distribution of Nyctinomops macrotis in the Inter-Andean Valley, Southern Ecuador. This record was done in an urban locality, placed in the inter-Andean Valley at $2,545 \mathrm{~m}$, contributing to improve the knowledge of this species distribution; besides, adding the highest record as well as new locality for Ecuador.

Keywords: Inter-Andean Valley; Lowlands; Azuay Province; Cuenca Municipality.

Received March 15, 2017

Accepted June 17, 2017

Released June 30, 2017

Open Acess Full Text Article

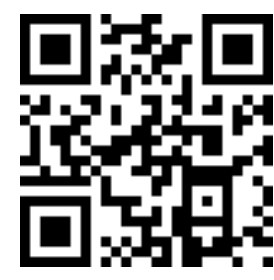

ORCIID

(1) 0000-0002-4016-331X Francisco SánchezKarste

(D) 0000-0002-8502-3150 Carlos NiveloVillavicencio

(1) 0000-0002-7203-8468 Javier Fernández de Córdova

D 0000-0002-9945-9414 Pedro X. Astudillo
Currently there are four species of the genus Nyctinomops (Miller, 1902) recognized in the new world, N. aurispinosus (Peale, 1848),
$N$ femorosaccus (Merriam, 1889), $N$. laticaudatus (É. Geoffroy and St.-Hilaire, 1805), and N. macrotis (Gray, 1840) (Koopman, 1982; Simmons, 2005), 
the last two species occurs in Ecuador (Tirira, 2016).

The big free-tailed bat Nyctinomops macrotis (Gray, 1840) is distributed from Southwestern Canada thorough Western United States and México, Central America, and South America in Colombia, Ecuador, Peru, Brazil, Bolivia, Uruguay and Northern Argentina (Simmons, 2005; Gardner, 2007) within an elevation range from 0 to 2,600 m (Milner et al., 1990). In Ecuador this species occurs in East lowlands, Pastaza province as well as west lowlands, Santa Elena, Guayas (Durán) and Manabí (Chone) provinces across an elevation range from 50 to $950 \mathrm{~m}$ (Allen, 1914; Albuja, 1999; Tirira, 2007). In addition, N. macrotis commonly inhabit caves, tree holes and buildings in urban areas (Barbour and Davis 1969).

Morphologically the species of $N$. macrotis is the largest member of genus, the dorsal pelage is glossy, varying from a pale reddish brown to dark brown, with bicolored hairs and the basal portion nearly white. This species has a large ears joined at the middle line, and when laid forward reach the snout, an antitragus which is higher than wide, a small and rectangular tragus, wrinkled upper lips, very deep basisphenoid pits, upper incisors parallel and separated from each other by a gap due to a long-narrowly maxillar and the third commissure of $\mathrm{M}^{3}$ (third upper molar) which is well developed and as long as the second (Gregorin, 2000; Gregorin and Taddei, 2002; Eger, 2007).

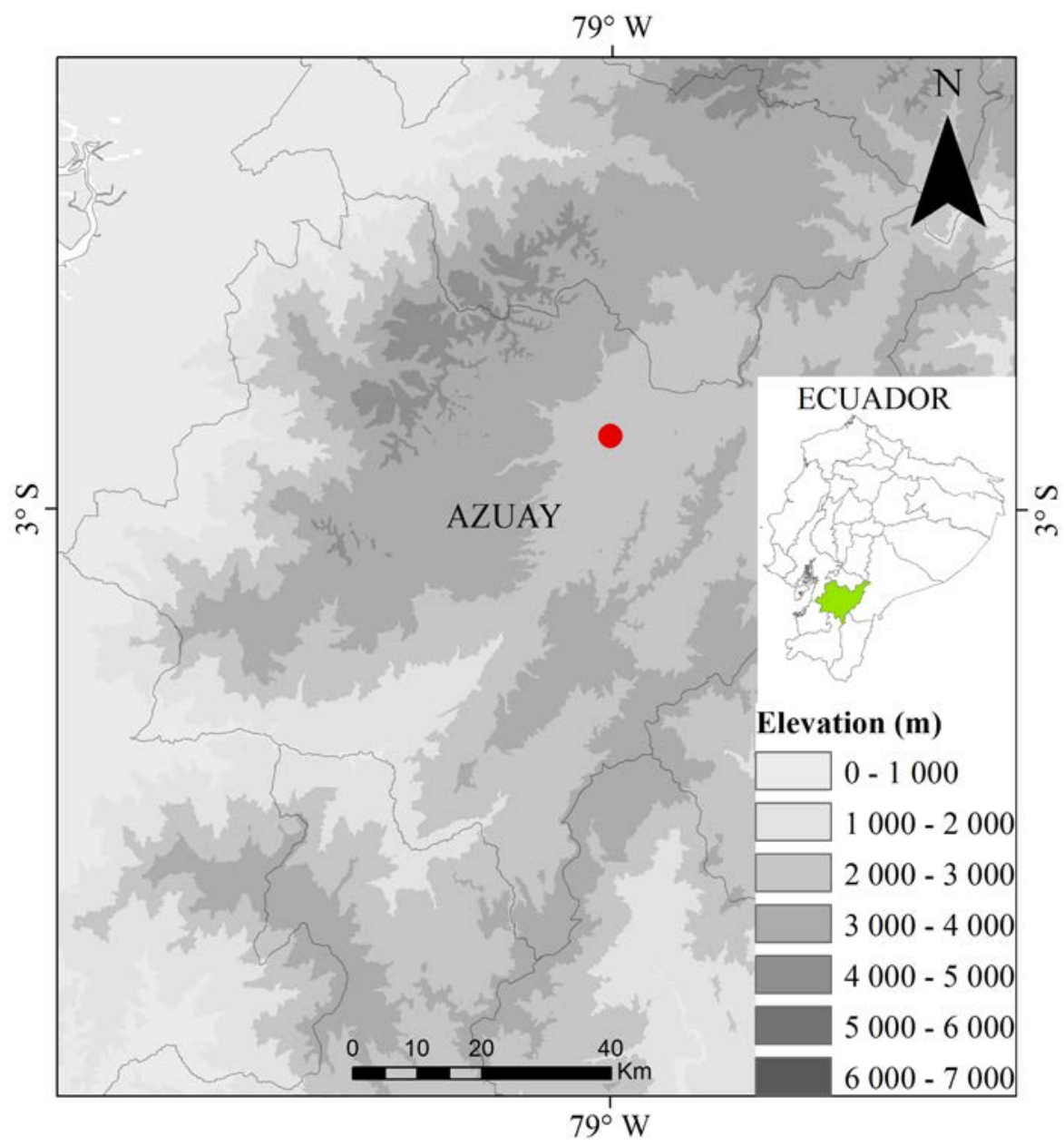

Figure 1. New locality of Nyctinomops macrotis in Ecuador. The red circle represents the new locality in Cuenca Municipallity, Intern-Andean Valley in Azuay Province (in green) from Ecuador. 
On 28 October 2014, an adult male of $N$. macrotis we found death in the downtown of Cuenca Municipallity ( $2^{\circ} 53^{\prime} \mathrm{S}, 79^{\circ} \mathrm{W} ; 2,545 \mathrm{~m}$ ), Southern Andes of Ecuador (Figure 1). The average temperature in Cuenca is around $15^{\circ} \mathrm{C}$, the rainy season begins in October to early May. The infrastructure in the downtown is a mosaic between old and modern buildings, there are several churches with large domes and colonial houses.

The specimen reported is big bodied with dorsal fur glossy and brownish (Figure 2A) and, the basal portion pale almost white. The ventral pelage contrast slightly with the back (Figure 2B). The upper lip is very wrinkly, the ears are large and joined at the middle line (Figure 2C, $2 \mathrm{D}, 2 \mathrm{E}$ ). Tail is $42 \%$ of the total body length. The braincase is moderately wide and the basisphenoid pits are deep (Figure 3A, 3B). The skull is elongated and flattened, the jaw is fragile and long (Figure 3C, 3D). This specimen was deposited in The Zoology Museum of Universidad del Azuay (MZUA) under code MZUA-MA263, the sample was identified according to external and cranial morphometric measurements (Table 1).

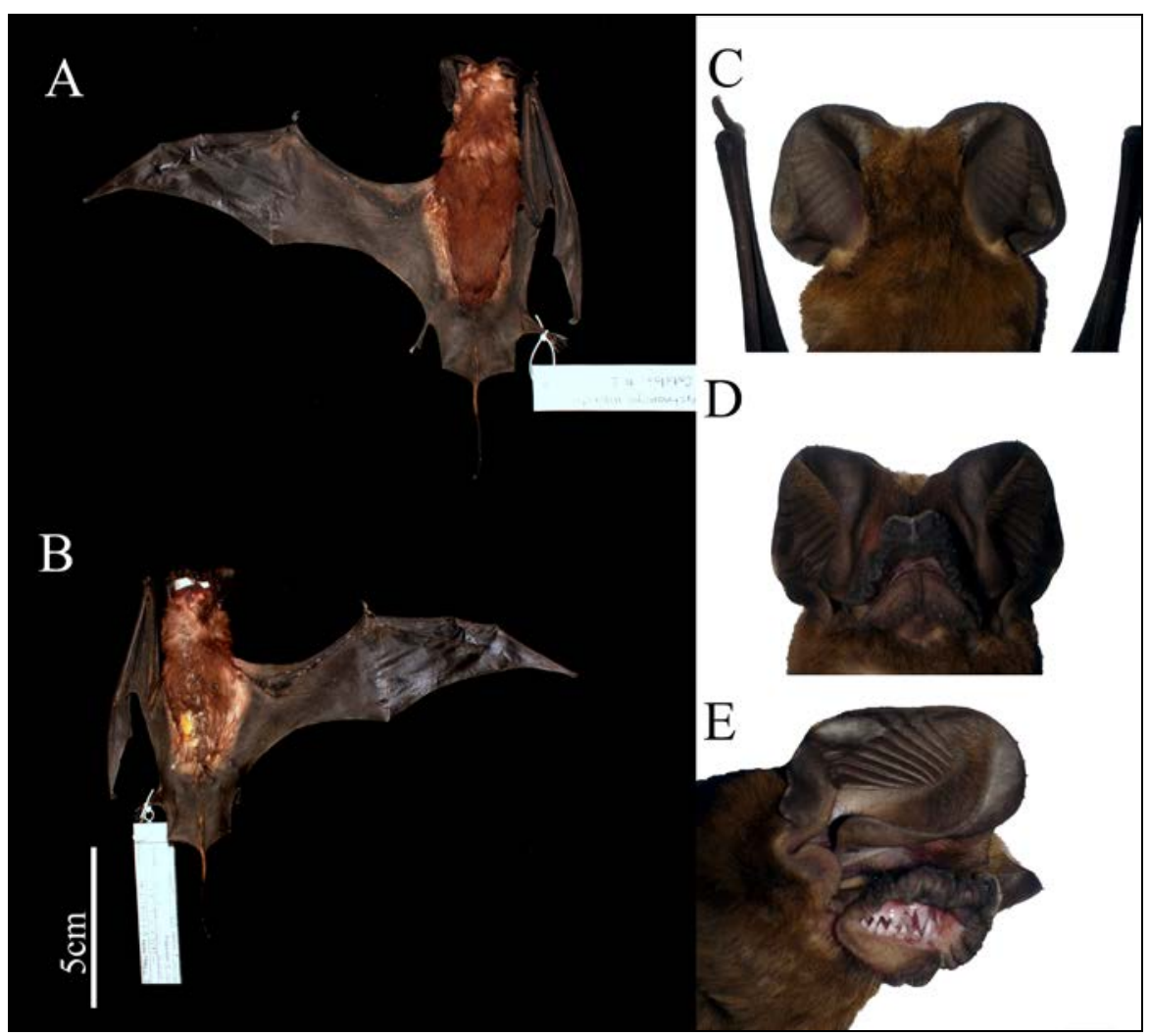

Figure 2. Specimen of Nyctinomops macrotis recorded in Cuenca Municipallity, Azuay Province in the South Intern-Andean Valley from Ecuador. The views are A) dorsal view and B) ventral view. C) back head view, D) frontal head view and E) lateral head view. 


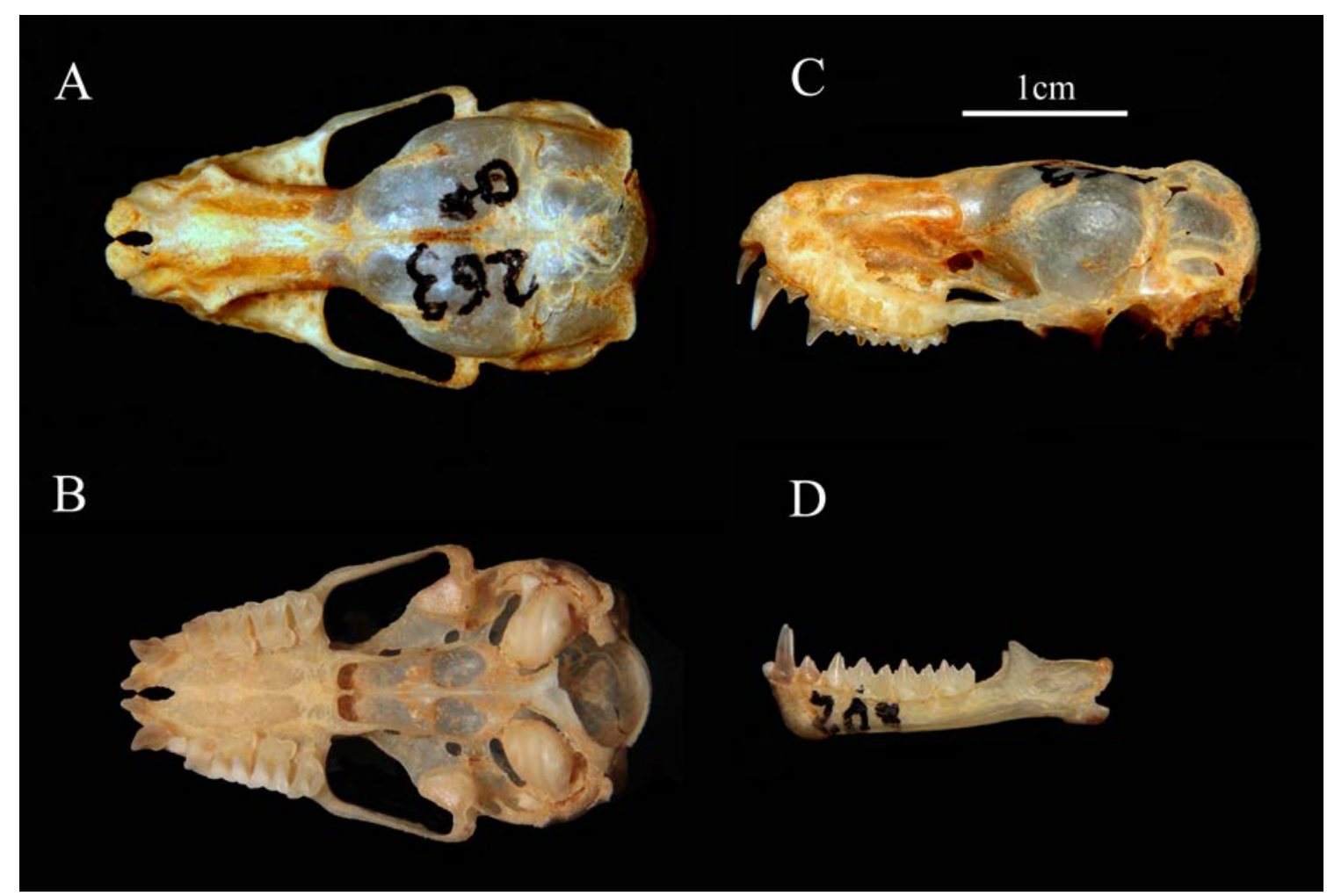

Figure 3. Specimen of Nyctinomops macrotis recorded in Cuenca Municipallity, Azuay Province in the South Intern-Andean Valley from Ecuador. The views are A) Dorsal skull view; B) ventral skull view; C) lateral skull view; and D) lateral mandibular view.

Table 1. Main external and skull measurements of an adult male of Nyctinomops macrotis MZUAMA263) recorded in southern inter-Andean valley, Ecuador.

\begin{tabular}{lc}
\hline Variable & Measurement (mm) \\
\hline Total length & 144 \\
Tail length & 74 \\
Foot length & 11 \\
Ear length & 23 \\
Forearm length & 64 \\
Condyloincisor length & 22.34 \\
Zygomatic breadth & 13.11 \\
Breadth at mastoids & 11.72 \\
Least inter-orbital width & 4.22 \\
Rostral length & 10.33 \\
Height of braincase & 8.11 \\
Palatal length & 7.61 \\
Upper tooth row (C-M $\left.{ }^{3}\right)$ & 8.90 \\
Lower tooth row (C-M & 9.20 \\
Moment arm of masseter & 3.51 \\
Mandibular length & 16.65 \\
\hline
\end{tabular}

This record is the first documented for $N$. macrotis in the Southern InternAndean Valley, specifically for the Azuay
Province. Thus, the present report become a new locality in the latitudinal distribution and implies a range altitudinal extension of 
$1,495 \mathrm{~m}$ in Ecuador. The geographical distance between the other records and this new locality shows, at least, the species distributed locally throughout Intern-Andes Region, although more studies is needed.

\section{Acknowledgements}

To the Universidad del Azuay and Jacinto Guillén for the support provided to this research. Juan Carlos Sánchez for his collaboration with the photographs. Veronica Leiva for the taxidermy. This work was done under the patent of the Museum of Zoology of the Universidad del Azuay, FAU.S-UDA-MUSEO DE ZOOLOGÍA-003-2016 and the project 2016-42 of Bioacoustics Models.

\section{Conflicts of interest}

Authors declare that they have no conflict of interests.

\section{References}

Albuja, L. Murciélagos del Ecuador. 2 ed. Quito: Cicetronic, 1999.

Allen, J. A. New South American bats and a new octodont. Bulletin of the American Museum of Natural History, v. 33, p. 381-389, 1914.

Barbour, R. W.; Davis, W. H. Bats of America. Lexington: University Press of Kentucky, 1969.

Eger, J. L. Family Molossidae. In: Gardner, A. L. (ed.). Mammals of South America. Vol. 1: marsupials, xenarthrans, shrews, and bats. Chicago: The University of Chicago Press, 2007. p. 399-440.

Gardner, A. L (ed.). Mammals of South America. Vol. 1: marsupials, xenarthrans, shrews, and bats. Chicago: The University of Chicago Press, 2007.
Gregorin, R. Filogenia de Molossidae Gervais, 1855 (Mammalia: Chiroptera). São Paulo: Universidade de São Paulo, 2000. (Tese de Doutorado).

Gregorin, R.; Taddei, V. A. Chave artificial para determinação de molossídeos brasileiros (Mammalia: Chiroptera). Mastozoología. Neotropical, v. 9, no. 1, p. 13-32, 2002. Available from: <http://www.sarem.org.ar/wpcontent/uploads/2012/11/SAREM_MastNeotrop _9-1_03_Gregorin.pdf $>$. Accessed on: Feb. 22, 2017.

Koopman, K. F. Biogeography of the bats of South America. In: Mares, M. A.; Genoways, H. H. (eds.). Mammalian Biology in South America. Pittsburgh: University of Pittsburgh Press, 1982. p. 273-302.

Milner, J.; Jones, C.; Jones Jr., J. K. Nyctinomops macrotis. Mammalian Species, v. 351, p. 1-4, 1990. Available from: <http://www.science.smith.edu/msi/pdf/i00763519-351-01-0001.pdf $>$. Accessed on: Feb. 22, 2017.

Simmons, N. B. Order Chiroptera. In: Wilson, D. E.; Reeder, D. M. (Eds.). Mammal species of the World: a taxonomic and geographic reference. Baltimore: Johns Hopkins University Press, 2005. p. 312-529.

Tirira, D. Guía de campo de los mamíferos del Ecuador. Quito, Ediciones Murciélago Blanco, 2007. (Publicación especial sobre los mamíferos del Ecuador, 6).

Tirira, D. G. Mammals of Ecuador: updapted checklist species. Versión 2016.1. Quito: Asociación Ecuatoriana de Mastozoología y Fundación Mamíferos y Conservación, 2016. (Updated: 2016-07-12). 